\title{
PARIS CLIMATE SUMMIT AND TURKEY'S RENEWABLE ENERGY POLICIES
}

\section{ÇELEBİ BOZ Füsun, BAYRAMOĞLU Turgut}

Bayburt University, Bayburt, Turkey

\begin{abstract}
The increase in population and urbanization which emerged together with industrialization have brought the increase in energy demand with them. Carbon emissions rise as a result of the increase in energy demand and lead to climate change. Such changes in climate have negative effects on not only the environment but human life as well. Therefore, countries should implement energy policies with low carbon density in order to reduce greenhouse gas emission. In this context, preferring renewable energy sources can prevent temperature increase by reducing the effects of fossil fuels on the environment. Turkey should attach importance to renewable energy sources and invest in these sources in accordance with the commitments accepted at the Paris Climate Summit in order to reduce carbon emission.
\end{abstract}

Keywords: Climate; Greenhouse Gas; Low Carbon Density; Paris Climate Conference; Turkey.

\section{Background}

After the Second World War, policies on industrialization and increasing production volume in order to enable the economic development of the countries came to the fore. In the 1970s, arguments suggesting that there cannot be human without the environment and economic growth will be achieved by transferring the environmental factors to future generations became the most important topic discussed internationally. The phenomenon defined as sustainable development was understood on the basis of economic development with the environment as reducing the greenhouse gas emission causing climate change and increasing the use of environmentally friendly energy sources. In this context, it was attempted to attract the interest of the world to the environment and climate change by various meetings organized to raise awareness of the countries.

The first international initiative on the environment took place in 1972 with Stockholm Conference, and it was stated during this conference that all humanity and governments were responsible for protecting and improving the environment for economic development (United Nations, Report of The United Nations Conference on the Human Environment, 1972). Later, affected by Stockholm Conference, the report called "Our Common Future" was prepared in 1987 as a result of the initiatives of the United Nations World Commission on Environment and Development. In this 
DOI: 10.1515/arhss-2016-0006

Applied Research In Health And Social Sciences: Interface And Interaction, Vol. 13, No. 1, 2016

report, which was called "Brutland Commission Report", sustainable development was defined as meeting the needs of today's generation without threatening the needs of future generations (Kates et al. 2005). The interest in the subject increased because of the developments such as Rio Environment Conference Climate Change Convention, Convention on Biological Diversity, Rio Declaration, Agenda 21, Protection and Improvement of the Forests in 1992. At this conference, it was agreed that the amount of gas reaching the air would be kept at the level of 1990 and the emphasis that the environmental and economic development should be considered together came to the fore. The protection of biological resources and prevention of the threats to these resources and the development of the measures against the unauthorized use of the resources and providing additional financial sources for the countries were also stated at this meeting (Alada et al., 1993). It was stated at the sustainable development conference organized by the United Nations in 2002 that environmental degradation increased and the effects of climate changes caused natural disasters, and measures must be taken. In other words, it was emphasized that environmental disasters such as drought and floods were caused by climate change and it was necessary to carry out and develop studies to eliminate the negative effects of climate change (UN, 2012). The need to struggle with the negative effects caused by climate change was stated at Rio +20 Conference; at the same time, within the context of green economy, it was aimed to reduce the greenhouse gas emission and keep the temperature increase over 1.5 degrees Celsius and below 2 degrees Celsius until 2020. For this purpose, environmental degradation and climate change were attempted to be prevented by determining energy policies such as giving importance to renewable energy sources, the use of low-density technologies and achieving energy efficiency UN, 2012).

Starting from the phenomenon that climate change has an effect on environmental degradation, the World Climate Conference was held in 1979. The negative effects and prevention of the damage caused by the human to the environment were focused on at this conference. In addition, it was aimed to set forth the changes in order to reduce climate change by using the knowledge of the humanity on climate (Zillman, 2009). Several conferences such as Villach (1985) and Toronto (1988) were held on climate change were held, however, the main step was taken by the United Nations Environment Program and World Meteorological Organization through the Intergovernmental Panel on Climate Change (Karakaya \& Ozcag, 2004). At the same time, international negotiations were started in 1990 in order to emphasize human-induced climate change. As a result of these initiatives, the Framework Convention on Climate Change was signed in 1992. Countries were classified into three groups by the Framework Convention that came into force in 1994 as countries included in Annex- $\mathrm{I}^{1}$, Annex-

\footnotetext{
${ }^{1}$ Countries in Annex-I are OECD members, EU members and countries switching to market economy. The responsibilities of these countries are to limit the green house gas emission, protect and develop areas absorbing greenhouse gases, report the measures they take and the policies they follow in this regard.
} 
DOI: $10.1515 /$ arhss-2016-0006

Applied Research In Health And Social Sciences: Interface And Interaction, Vol. 13, No. 1, 2016

$\mathrm{II}^{2}$, and countries not included in annexes ${ }^{3}$. Turkey, which had been among the countries included in Annex-II at first, was later excluded from this group and included in Annex-I taking its special conditions as a developing country in 2001. It was admitted that Turkey was not obliged to provide financing and technology transfer because of its different conditions (General Directorate of State Hydraulic Works, 2016). No specific target was determined in terms of reducing greenhouse gas emission in the Framework Convention on Climate Change, the main change related to greenhouse gas emission was realized with the Kyoto Protocol (Barbour, 2010).

In this study, the Kyoto Protocol for reducing the greenhouse gas emission caused by humaninduced climate change and climate summits following the protocol, policies on renewable energy and Turkey's obligations in the reduction of carbon emission and its renewable energy policy will be examined.

\section{Kyoto Protocol and Carbon Emission}

The Kyoto protocol can be defined as the first international treaty containing binding targets on reducing greenhouse gas emissions. According to the treaty, it was agreed that the greenhouse gas emissions of the countries included in Annex-I would be reduced to at least 5\% below the amount of 1990 in the 2008-2012 period and the temperature rise would be limited to 2 degrees Celsius (UN, Kyoto Protocol To The United Nations Framework Convention On Climate Change, 1998). Furthermore, depending on national targets of the countries (for example, within the obligation period, New Zealand's target is $100 \%$ of 1990 level, Australia's target is $108 \%$ of 1990 level and EU's target is $92 \%$ of 1990 level), mechanisms were identified in the protocol in order to enable these countries to achieve their targets in a flexible and effective way. These mechanisms are international emission trade, clean development mechanism, and co-execution; the objectives were achieved through these mechanisms (Boston, 2008). While the co-execution mechanism provides an opportunity for industrialized countries to carry out joint projects with other developed countries, the clean development mechanism includes sustainable development projects to reduce carbon emissions (UNFCCC, United Nations Framework Convention on Climate Change Fact sheet: The Kyoto Protocol, 1997). The Kyoto protocol was approved by other countries except the USA, and no targets were set for developing countries like China. Although signed in 1997, the protocol came into force mainly in 2005 and all signatories were held responsible for global warming and climate change by the international framework text (IKKV, 2013).

\footnotetext{
2 Countries in Annex-II are 23 countries and EU member countries that are responsible for, in addition to the obligations of Annex-I countries, transferring environmentally friendly technologies to signatory countries and making effort to enable these countries to achieve these technologies.

${ }^{3}$ Countries not included in annexes are the group of countries consisting of 153 countries having no certain obligations but which are encouraged to reduce greenhouse emission, make cooperation on the research and technologies and protect the areas absorbing greenhouse gases.
} 
DOI: $10.1515 /$ arhss-2016-0006

Applied Research In Health And Social Sciences: Interface And Interaction, Vol. 13, No. 1, 2016

Following the Kyoto protocol, although there was no certainty about the obligations of the countries and the duration of the protocol was unknown, the decrease in investments in energy resources with low carbon density led to the start of the second commitment process and the parties needed to consider a new convention on climate change. For this purpose, considering that the obligations were not fulfilled, a conference of signatories was held in Bali in 2007 in order to determine a new road map (Boston, 2008; IKV, 2013). The Bali conference was binding in terms of not only the developed countries but also developing countries as well, and for the first time developing countries also became parties to the reduction of greenhouse gas emissions.

Table 1

Carbon Emissions Reduction Targets Within the Framework of the Kyoto Protocol

\begin{tabular}{|c|c|c|}
\hline Countries & \begin{tabular}{|l} 
Kyoto Target for 2008- \\
2012 \\
\end{tabular} & 2020 Target \\
\hline Australia & $8 \%$ over 1990 level & $5 \%$ below 2000 level \\
\hline Canada & $6 \%$ below 1990 level & $17 \%$ below 2005 level \\
\hline $\begin{array}{l}\text { European } \\
\text { Community }^{4}\end{array}$ & $8 \%$ below 1990 level & $20 \%$ below 1990 level \\
\hline Bulgaria & $8 \%$ below 1988 level & $20 \%$ over 2005 level \\
\hline Czech Republic & $8 \%$ below 1990 level & $9 \%$ over 2005 level \\
\hline Japan & $6 \%$ below 1990 level & $25 \%$ below 1990 level \\
\hline New Zealand & At 1990 level & 10-20\% below 1990 level \\
\hline Russia & At 1990 level & $15-25 \%$ below 1990 level \\
\hline $\begin{array}{l}\text { The United States of } \\
\text { America }\end{array}$ & - & $17 \%$ below 2005 level \\
\hline Norway & $1 \%$ over 1990 level & $30 \%$ below 1990 level \\
\hline Ukraine & At 1990 level & $20 \%$ below 1990 level \\
\hline United Kingdom & $12.5 \%$ below 1990 level & $16 \%$ below 2005 level \\
\hline India & - & $\begin{array}{l}20-25 \% \text { reduction in emissions per unit of GDP from } \\
2005 \text { level }\end{array}$ \\
\hline China & - & $\begin{array}{l}40-45 \% \text { reduction in emissions per unit of GDP from } \\
2005 \text { level }\end{array}$ \\
\hline Brazil & - & $\begin{array}{l}36.1-38.9 \% \text { below business-as-usual projected emissions } \\
\text { level in } 2020\end{array}$ \\
\hline South Korea & - & $4 \%$ below 2005 level \\
\hline South Africa & - & $34 \%$ below business-as-usual projected emissions in 2020 \\
\hline Israel & - & $20 \%$ below business-as-usual projected emissions in 2020 \\
\hline
\end{tabular}

Source: Center for Climate and Energy Solutions, (D.A.: 01.04.2016)

${ }^{4} 27$ countries of the European Union made a commitment to be $20 \%$ below the 1990 level in 2020. 
Thus, with this conference, which is also known as the Bali Roadmap, a treaty to be binding on all parties was aimed to be determined at the end of a two-year period. This agreement established the base for the Copenhagen Climate Change Convention in 2009. At the same time, protection of poor countries against climate changes through emergency measures, providing foreseeable and sustainable financial resources were also among the decisions taken. The most important aspect of the Bali agreement is that it defined carbon emissions in a measurable, verifiable and reportable manner and created a situation in which developing markets such as China would be a party to the carbon emission reduction measurements. Considering the fact that the Kyoto protocol would expire in 2012, what procedures would be followed regarding climate change was started to be discussed. In this context, the Climate Change Conference was held in Copenhagen in 2009. As a result of the conference, the upper limit of the rise in the global temperature was aimed to be 1,5 or 2 degrees Celsius, and the reduction in the carbon emission in 2050 was aimed to be 50\% (Bodansky, 2010). At the Copenhagen conference, it was also emphasized that science-based, realistic, prescient and achievable targets should be determined and that the second commitment period of the Kyoto Protocol should be evaluated through measuring, reporting, adequate reducing activities for developing countries and verification mechanismsc (Thorvaldsdottir \& Valdre, 2009). In terms of the financing aspect of the reduction of greenhouse gas emissions, it was stated at the conference that the developed countries should provide 30 billion USD for 2010 and 2012 and 100 billion USD each year until 2020 (The Climate Group, A Climate Group Assesment, 2010). The emission reduction must be 10-40\% below the level of 1990 in order to limit the temperature rise. The rates were determined by the countries to achieve this ratio by 2020 (Ottinger, 2010).

Before the Paris Climate Summit, conferences were held in Warsaw in 2013 and in Lima in 2014. A mechanism was established at the Warsaw conference to assess the loss and damage caused by climate change, however, no action plans were accepted by the developed countries due to additional funding measures. At the Lima conference, a new convention in which common principles would be accepted and different responsibilities would be determined was brought to the forefront. Additionally, with the announcement of the action plans and targets for the period after 2020 of China and the USA, which was considered as a positive development in terms of continuing negotiations on climate, the text of a new agreement at the Paris Climate Summit to be held in 2015 became inevitable (Xue-Du, 2014; Yu-Li, 2015).

\section{Paris Climate Conference and Renewable Energy Resources}

With the increase in global warming, it was necessary to clarify the new action plans on climate change. Especially the fact that the temperature rise will reach at least 3-4 degrees Celsius in 2100 will 


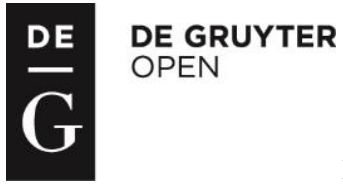

DOI: $10.1515 /$ arhss-2016-0006

Applied Research In Health And Social Sciences: Interface And Interaction, Vol. 13, No. 1, 2016

threaten both food security and the availability of water. Therefore, countries have liabilities regarding the reduction of greenhouse gas emissions. Transition to low carbon density economy and the development of international cooperation for the conservation of the natural environment are also among the other objectives of this convention (Aid, 2014).

Unlike the Kyoto Protocol, the Paris Climate Convention has targets regarding temperature increase (keeping the global temperature increase below 2 degrees Celsius, at the same time, ensuring that it is 1,5 degrees Celsius) and imposes liability on all developed and developing countries. Furthermore, it was stated that a 100 billion USD fund would be provided by the developed countries and the fund would be redesigned according to the new target in 2025. Being a convention imposing common but at the same time different responsibilities on each country by taking their capacities into account is its difference from the Kyoto Protocol (C2ES,Center for Climate and Energy Solutions, 2015).

The Paris Agreement can be described as the first global agreement on climate change that was adopted by 195 countries. For this reason, keeping the fact of global warming in mind, the countries should invest in renewable energy resources in order to reduce carbon emission. According to the forecasts of the International Renewable Energy Agency, the share of renewable energy resources will double in 2030 and the temperature rise will be below 2 degrees Celsius thanks to energy efficiency. It is stated that even if the countries fulfill their liabilities, the temperature rise will be $2.7{ }^{\circ} \mathrm{C}$ in 2100 , and as a result of the current emission reduction policies, emission density in the electric sector will decrease to $488 \mathrm{~g} / \mathrm{kwh}$ from $575 \mathrm{~g} / \mathrm{kwh}$ in 2030 , and as a result in the increase in renewable energy resources, it will be $362 \mathrm{~g} / \mathrm{kwh}$ of the level in 1990 (IRENA, 2015). Upon examining the increase in carbon emissions, it can be said that it increased from 1973 until 2013, and carbon emission, which had been $15.515 \mathrm{mt}$ in 1973 increased to $32.190 \mathrm{mt}$ in 2013(IEA, 2015). While $66.3 \%$ of carbon emissions were caused by OECD countries, the share of OECD decreased to $34.3 \%$ in 2013; the shares of China and Asian countries in the increasing emission rate were $28 \%$ and $11.2 \%$, respectively. In this period, the shares of Europe and Eurasia not including Asia decreased and reached $8 \%$ while the share of the Middle East, which had been $0.8 \%$ in 1973, reached $5.1 \%$ in $2013^{5}$.

\footnotetext{
${ }^{5}$ The term of Asian countries includes Asian countries except China.
} 


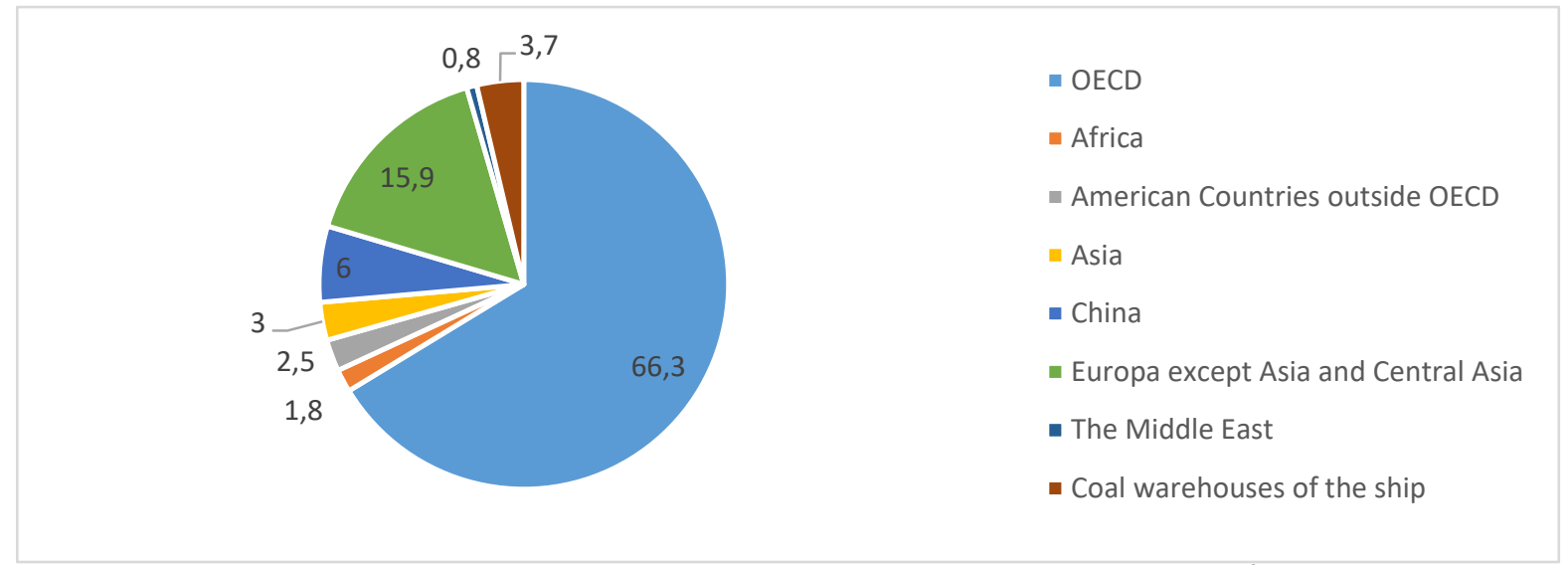

Figure 1. Carbon Emission Rates of the Countries in $1973(\%)^{6}$

When the elements that make up carbon emissions are examined, it is seen that the share of petroleum products which had been $49.7 \%$ in 1973 decreased to $33.6 \%$ in 2013 . Upon examining the share of coal, which had been $35.9 \%$, it is seen that it rose to $46 \%$ in 2013 , and the share of natural gas reached $19.8 \%$ in 2013 by slightly increasing. Thus, a large portion of carbon emissions was caused by fossil fuels. Because carbon emissions will decrease as the share of fossil fuels decreases, the negative effects of climate change will be eliminated.

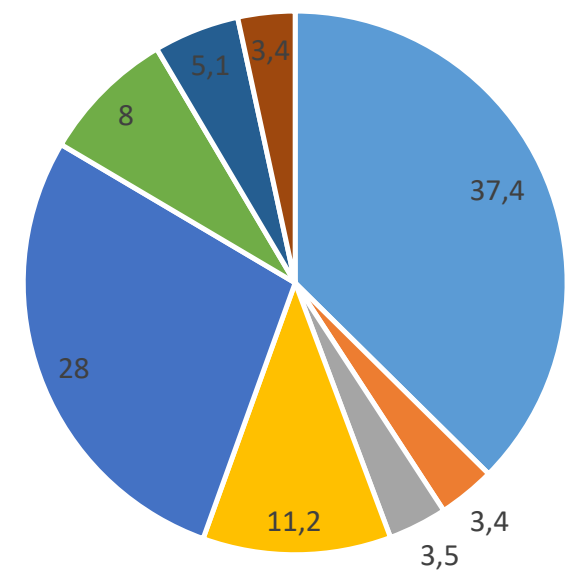

Figure 2. Carbon Emission Rates by Region in $2013(\%)^{7}$ $\because \mathrm{OECD}$

- Africa

- American Countries outside OECD

Asia

- China

- Europa except Asia and Central Asia

- The Middle East

- Coal warehouses of the ship

Source: IEA, Key World Energy Statics, 2015 (1.04.2016)

\footnotetext{
6 Carbon emission rates are based on the energy balance of the International Energy Agency and the Intergovernmental Climate Change Panel held in 2006.

${ }^{7}$ Included with peat and schist coal.
} 


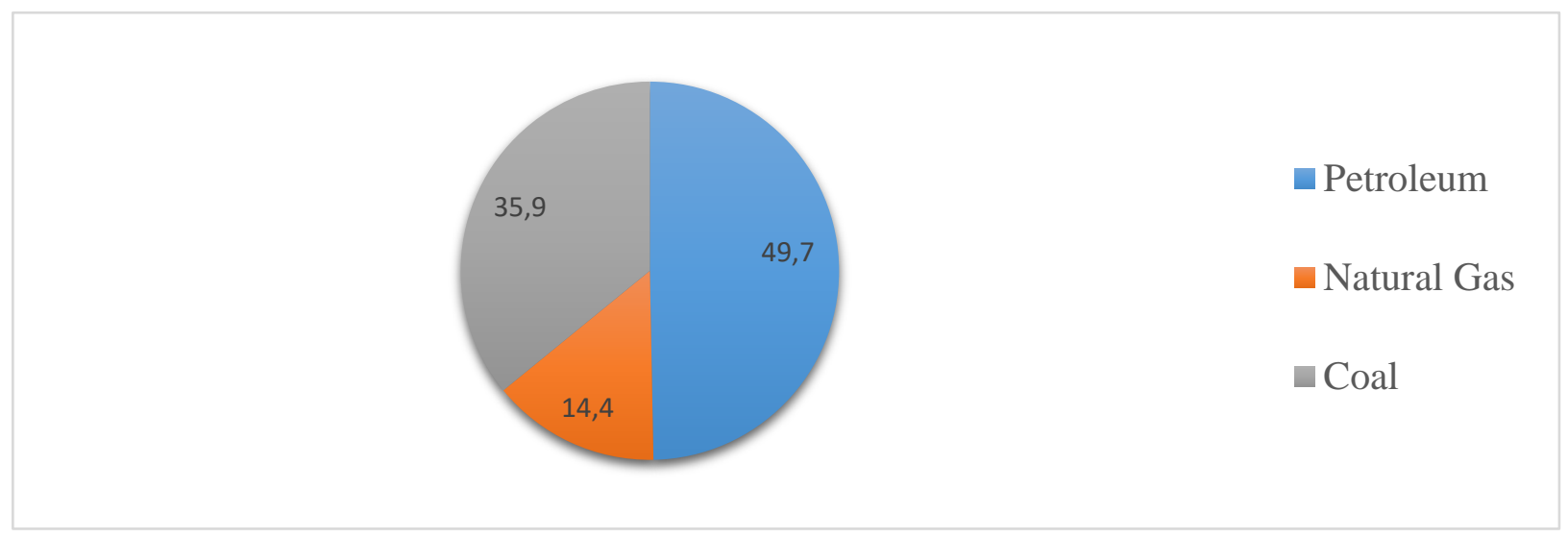

Figure 3. Share of Fossil Fuels in Carbon Emissions in $1973(\%)^{8}$

Renewable energy resources, which are fuels with low carbon density, and nuclear energy should be preferred in order to reduce the share of carbon emissions. However, some countries in the world are observed to have canceled or limited nuclear energy power plant projects due to the damages occurring as a result of especially natural disasters in nuclear energy. Therefore, renewable energy resources with low carbon density should be preferred instead of nuclear energy and investments should be made in these resources.

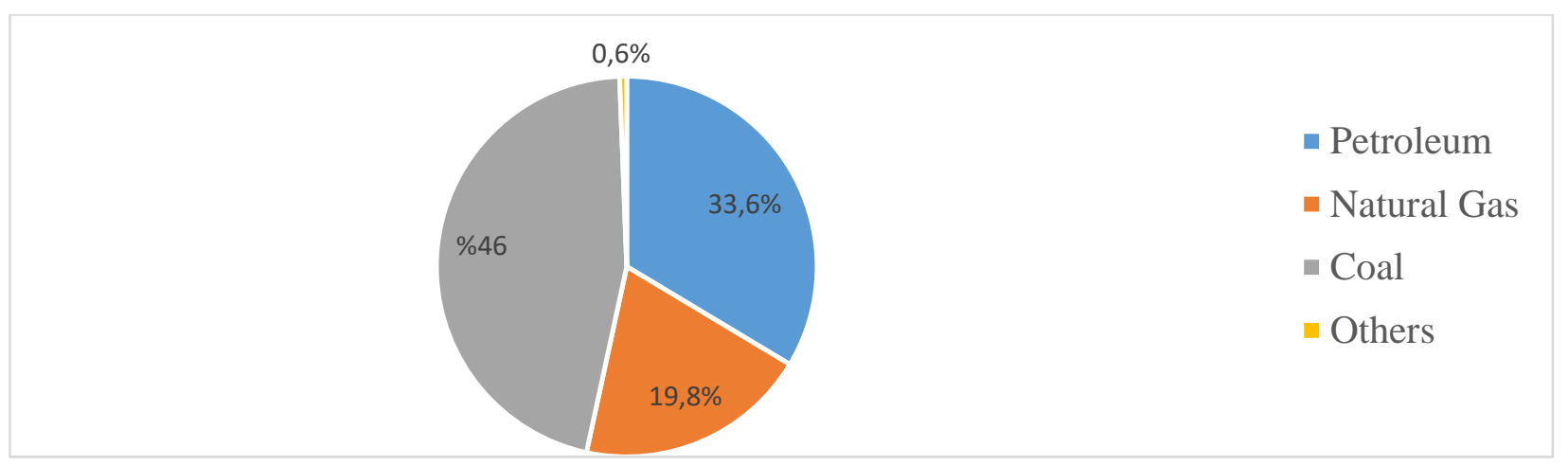

Figure 4. Share of Fossil Fuels in Carbon Emissions in 2013 (\%)

Source: IEA, Key World Energy Statics, 2015 (1.04.2016)

When the share of renewable energy resources within the primary energy in the world is examined, it can be said that it has been increasing since the 2000s and gained a rapid momentum after 2010. It is predicted that its share will rise to approximately $5 \%$ by 2025 . It can be also observed that the share of natural gas increases while the share of petroleum products decreases. The share of coal fluctuated until 2010 and tended to decrease after 2010. However, the increase in fossil fuels will still be larger than the renewable energy resources and will constitute approximately $90 \%$ by 2025 .

\footnotetext{
${ }^{8}$ Its other meaning includes industrial waste and non-renewable public waste.
} 
DOI: 10.1515/arhss-2016-0006

Applied Research In Health And Social Sciences: Interface And Interaction, Vol. 13, No. 1, 2016

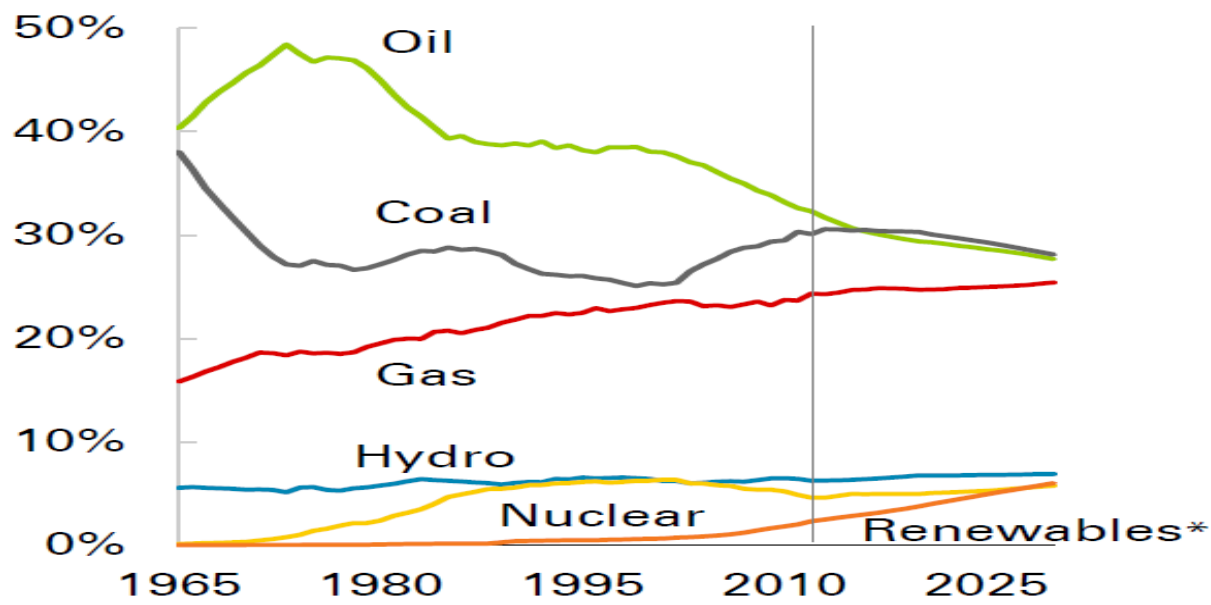

Figure 5. Share of Primary Energy Resources in the World (\%) (E.T.: 19.04.2016)

Source: BP Energy Outlook, 2030 http://www.bp.com/content/dam/bp/pdf/energy-economics/energy-outlook-2015/bp-energy-outlookbooklet_2013.pdf

It can be said that the share of renewable energy resources in electricity production is lower than that of fossil fuels. As can be seen from Table 2 below, the share of fossil fuels in electricity production was rising by years and was around $78 \%$ in 2014 . With hydro-electric power generation, the share of renewable energy resources except hydro-electric (the sun, wind, geothermal and biomass) increased and reached $6.2 \%$ in 2014.

Table 2

The Share of Energy Types in Electric Energy in the World During 2010-2014 Period

\begin{tabular}{|l|c|c|c|c|c|}
\hline Energy Types (\%) & $\mathbf{2 0 1 0}$ & $\mathbf{2 0 1 1}$ & $\mathbf{2 0 1 2}$ & $\mathbf{2 0 1 3}$ & $\mathbf{2 0 1 4}$ \\
\hline Fossil Fuels & 67.6 & 79.7 & 78.3 & 77.9 & 77.2 \\
\hline Hydro-electric & 16.1 & 15.3 & 16.5 & 16.4 & 16.6 \\
\hline Renewable energy except hydro-electric & 3.3 & 5.0 & 5.2 & 5.7 & 6.2 \\
\hline Nuclear & 13 & - & - & - & - \\
\hline
\end{tabular}

Source: Prepared using the data of Ren 21, Global Status Report 2010-2014. - Means no data are available (E.T.: 19.04.2016)

\section{Turkey's Status with Regard to the United Nations Framework Convention On Climate Change (UNFCCC), Kyoto Protocol and Paris Climate Summit}

Environmental pollution as a result of climate change and economic activities is one of the most important socio-economic issues. The main source causing this effect is the increase in greenhouse gasses as a result of production and consumption activities. For this reason, there is no doubt that Turkey is closely related to the susceptibility on this issue in the international area. 


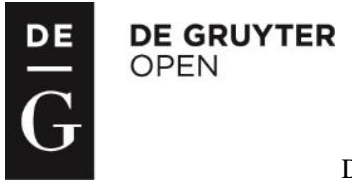

DOI: 10.1515/arhss-2016-0006

Applied Research In Health And Social Sciences: Interface And Interaction, Vol. 13, No. 1, 2016

Turkey became a party to UNFCCC (The United Nations Framework Convention On Climate Change) in 2004 which is the broadest-ever consensus text on climate change that came into force in 1994 with the participation of 195 countries. With this step taken in the international arena with regard to climate change, countries were given common but different responsibilities with regard to reducing current greenhouse gas emissions taking into account each country's special conditions. The rationale for giving different responsibilities to each county is that it was thought that following the Industrial Revolution, some countries had caused climate change more than the others. Although Turkey had been in the group of Annex-II Countries at first, it was removed from this group and included into the group of Annex-I Countries in 2001 due to its special conditions as a developing country. It was accepted that Turkey had no obligation to provide financing and technology transfer due to its different conditions.

Turkey became a party to the Kyoto Protocol in 2009. The amounts of reduction for countries that are parties to the convention were identified for the period of 2008-2012, which was called as the first commitment period. According to this, these countries made a commitment to reduce their greenhouse gas emissions $5 \%$ below the level of 1990 within this period. Turkey did not undertake any action for this period, for it was not a party to UNFCCC during the negotiations for the Kyoto Protocol. Turkey has no obligation for the years of 2013-2030, which is the second period, like the first period. It should be noted that the status of Turkey is special under the Kyoto Protocol. Turkey, which was included in Annex-I list of the Agreement at the 7th Parties Conference held in Marrakech in 2001, is a country which is a party to the Kyoto Protocol but has no commitment with regard to greenhouse gas reduction or limitation.

International environmental awareness that had begun in 1992 managed to bring together 196 countries at the Climate Summit held in Paris in 2015. Since the current commitments of the countries that undertook obligations with regard to greenhouse gas emissions will expire in 2020, the emission ratios of the countries, which are the parties to the agreement, in 2030 were agreed on. At this summit, Turkey, for the first time, provided a letter of intent for greenhouse gas reduction and put itself under obligations. In this respect, the summit is different for Turkey from other summits on climate change. Turkey that had managed to be exempted from obligations in the protocols with regard to greenhouse emissions announced its National Contribution Notice of Intent to Combat Climate Change on 30 September 2015 that was one day before the summit. According to the statements made, Turkey is planning to increase its greenhouse gas emissions at the rate of $116 \%$ over 15 years by $5 \%$ per year. Based on these ratios, Turkey plans to reduce emission ratio by $21 \%$ based on the "decrease from increase method" within 2020-2030 period and increase its emissions from 430 million tons to 929 million tons by 2030 (Ministry of Energy and Natural Resources, Climate Change Negotiations and Turkey, 2016). 
DOI: 10.1515/arhss-2016-0006

Applied Research In Health And Social Sciences: Interface And Interaction, Vol. 13, No. 1, 2016

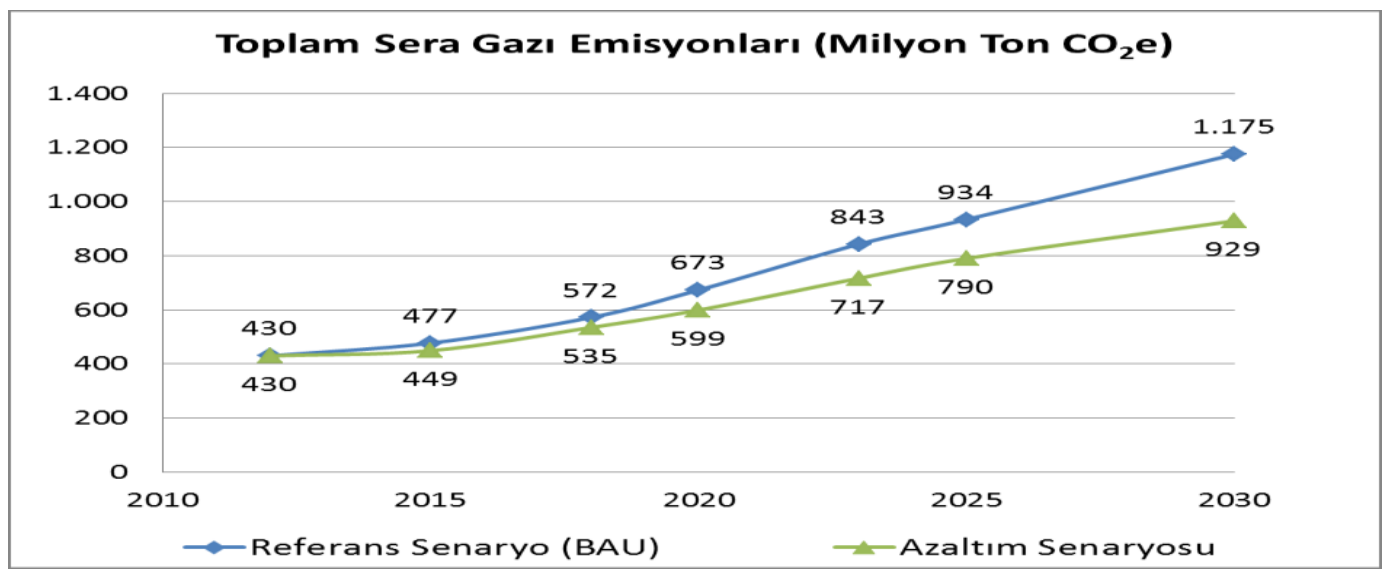

Figure 6. Scenario Based on Turkey's National Contribution Notice of Intent to Combat Climate Change Source: Republic of Turkey Intended Nationally Determined Contribution

It was agreed at the Paris Climate Summit that the parties to the agreement would limit the global warming below 2 degrees Celsius, developed countries would support developing countries in terms of financing, capacity and technology development, developed countries would provide 100 billion USD funding per year until 2020, a global inventory would be prepared in 2023 and then renewed every five years in order to measure the contributions of relevant countries on climate change. In order for the agreement to come into force, it must be signed until 2017 by 55 signatory countries that produce at least 55\% of the global greenhouse gas emissions (UN, FCCC/CP/2015).

As seen from Figure 6, Turkey guarantees to keep its total greenhouse gas emission under a certain level and increase it to 929 million tons in $\mathrm{C}_{2}$ equivalent by 2030 . However, according to the scenario prepared taking into account the socio-economic development of Turkey, greenhouse gas emissions in $\mathrm{CO}_{2}$ equivalent will reach 1.175 million tons. There is a deficit of 246 million tons that is equivalent to $21 \%$, between the greenhouse gas emission targets and the possible amount foreseen by the scenario.

\section{Renewable Energy Policies of Turkey}

As an emerging economy, Turkey has to increase the use of energy to achieve its socio-economic goals. However, Turkey is a country dependent on energy. Among the OECD countries, Turkey is the leading country in terms of the increase in energy demand, and, according to the forecasts made, it is understood that this trend will continue (Turkey's Energy Profile and Strategy, 2016). Turkey, which imports three-quarters of the energy it uses, is the fifth in the world in natural gas import, the thirteenth in oil import and the eighth in coal import. Turkey's primary energy demand increased by $127 \%$ and import increased by $211 \%$ between 1990 and 2013, however, domestic production stayed at 24\% (Türky1lmaz, 2015). 
DOI: $10.1515 /$ arhss-2016-0006

Applied Research In Health And Social Sciences: Interface And Interaction, Vol. 13, No. 1, 2016

According to the energy projection for Turkey, the energy demand which is currently 125 million TOE will reach 210 million TOE in accordance with 2023 targets (Ministry of Foreign Affairs of Turkey, 2016). If the country, the energy demand of which is expected to increase by $60 \%$ between 2014 and 2023, does not change the types of energy it uses, emission rates can be expected to rise. Turkey, like many other countries, wants to meet its energy demand through renewable energy resources. All countries have plenty of renewable energy resources. In addition, renewable energy is a type of energy that is preferred because of energy security, energy options, and low carbon content (IEA, 2016).

In its Letter of the Intended Nationally Determined Contribution, Turkey stated that it would reduce greenhouse gas emissions as a result of its studies on energy, industry, transportation, buildings and urban transformation, agriculture, waste and carbon sinks. However, because around $70 \%$ of greenhouse gas emissions arise from the energy sector, it may be considered appropriate to focus on this area (The Letter of the Intended Nationally Determined Contribution). Turkey has listed the works it plans to carry out by 2023 in the energy field. According to this:

- Solar energy production capacity will be increased to $10 \mathrm{GW}$,

- Wind energy production capacity will be increased to $16 \mathrm{GW}$,

- Full hydraulic capacity,

- 1 nuclear power plant will start operation,

- The loss in electricity generation and electricity transmission networks will be reduced to $15 \%$,

- State-run power plants will be renovated,

- On-site production, cogeneration, and micro cogeneration systems will be increased in electricity generation.

As understood from these targets, Turkey is planning to achieve its targets regarding greenhouse gas emissions set for the 2030s by increasing renewable energy production which is energies with low carbon content, starting production in the field of nuclear energy and studies on energy efficiency (Ministry of Environment and Forests of Turkey, 2009).

Turkey's target of transition to renewable energies is explained by the reasons such as population growth, high energy demand, the importance of the security of energy supply, climate change in Turkey's National Renewable Energy Action Plan. The necessity to use renewable energy resources in the production and consumption of energy in order to fulfill its commitments regarding climate change is also accepted by public authorities (Ministry of Energy and Natural Resources of Turkey, 2014). Again, in line with Turkey's 10th Development Plan, Turkey listed the works it planned to do in the field of energy in the Action Plan for Energy Production Based on Domestic Resources 
DOI: 10.1515/arhss-2016-0006

Applied Research In Health And Social Sciences: Interface And Interaction, Vol. 13, No. 1, 2016

Program. According to the report, the increasing fossil fuel import to meet the rapid growth in energy demand raises energy dependence; therefore, the transition to renewable energy resources in power generation must quickly be realized and the share of renewable energies in primary energy demand and electricity generation must be increased.

The amounts of energy planned to be produced using domestic resources are given in Table 3. According to this, the share of domestic resources in the increase in energy demand will be raised from $27 \%$ (the rate in 2012) to $35 \%$ in 2018 , the amount of energy produced from domestic coal resources will be raised from 32 billion $\mathrm{kWh}$ (the amount in 2013) to 57 billion kWh in 2018 and the hydraulic capacity will be raised by bringing new capacity of $10.000 \mathrm{MW}$ into operation by 2018 . The highest increase in the 2013-2018 period is anticipated in the renewable energy field. Domestic coal, petroleum and natural gas and hydraulic resources follow it. It is understood from the projections made that the aim is to reduce the share of fossil fuels and meet the energy demand by passing to renewable energy and nuclear energy technology.

Table 3

Projection for Energy Production Based on Domestic Resources

\begin{tabular}{|l|l|l|l|l|l|l|}
\hline Resources & $\mathbf{2 0 1 3}$ & $\mathbf{2 0 1 4}$ & $\mathbf{2 0 1 5}$ & $\mathbf{2 0 1 6}$ & $\mathbf{2 0 1 7}$ & $\mathbf{2 0 1 8}$ \\
\hline $\begin{array}{l}\text { The amount of electricity production } \\
\text { from domestic coal (TWh) }\end{array}$ & 32 & 43 & 54 & 57 & 57 & 57 \\
\hline $\begin{array}{l}\text { Petroleum and natural gas production } \\
\text { amount (barrel/day) }\end{array}$ & 72.000 & 91.200 & 99.800 & 111.700 & 112.100 & 121.600 \\
\hline $\begin{array}{l}\text { The amount of electricity produced } \\
\text { from hydraulic energy (TWh) }\end{array}$ & 59 & 66 & 74 & 80 & 86 & 91 \\
\hline $\begin{array}{l}\text { The amount of electricity produced } \\
\text { from renewable resources (Wind, solar, } \\
\text { geothermal, biomass) (TWh) }\end{array}$ & 10 & 13 & 16 & 20 & 24 & 29 \\
\hline
\end{tabular}

Resource: 10th Development Plan, Action Plan for Energy Production Based on Domestic Resources

What should be questioned here is whether Turkey will be able to reduce greenhouse gas emissions to the extent requested while trying to achieve its growth and development targets. It is known that the most important factor for growth targets is to increase the use of energy (Hamilton, 1983; Aydın, 2010; Soytaş \& Sar1, 2003; Yanar \& Kerimoglu, 2011). The activities that are the source of greenhouse gas emissions are energy, industrial processes, and the use of solvent products, agricultural activities, and waste (European Environment Agency, Annual European Union greenhouse gas inventory 1990-2013 and Inventory Report 2015). According to 2013 figures, the shares of energy, industrial processes and product use and agricultural activities and waste in greenhouse gas emissions were $82.2 \%, 17.6 \%, 0.2 \%$, respectively (Turkish Statistical Institute, 2013). 
DOI: $10.1515 /$ arhss-2016-0006

Applied Research In Health And Social Sciences: Interface And Interaction, Vol. 13, No. 1, 2016

In order to reduce $\mathrm{CO} 2$ emissions resulting from the field of energy, Turkey aims to increase its renewable energy production. Turkey set an estimation about what it would realize in the field of renewable energy by 2023 and what benefit it would get from greenhouse gas emissions based on energy by 2030. These values are shown in Table 4 below.

Table 4

The Expected Contribution of Renewable Energies to the Energy Sector in Turkey (2016-2023, GWh)

\begin{tabular}{|l|l|l|l|l|l|l|l|l|}
\hline & $\mathbf{2 0 1 6}$ & $\mathbf{2 0 1 7}$ & $\mathbf{2 0 1 8}$ & $\mathbf{2 0 1 9}$ & $\mathbf{2 0 2 0}$ & $\mathbf{2 0 2 1}$ & $\mathbf{2 0 2 2}$ & $\mathbf{2 0 2 3}$ \\
\hline Hydroelectric & 73.175 & 77.584 & 81.992 & 86.400 & 87.750 & 89.100 & 90.450 & 91.800 \\
\hline Wind power & 19.010 & 23.873 & 28.644 & 33.270 & 37.725 & 41.999 & 46.089 & 50.000 \\
\hline Solar energy & 1.280 & 2.880 & 3.840 & 4.800 & 5.760 & 6.400 & 7.040 & 8.000 \\
\hline Geothermal energy & 2.474 & 2.849 & 3.224 & 3.599 & 3.975 & 4.350 & 4.725 & 5.100 \\
\hline Biomass Energy & 2.071 & 2.422 & 2.774 & 3.126 & 3.477 & 3.829 & 4.181 & 4.533 \\
\hline Total & 98.010 & 109.608 & 120.474 & 131.196 & 138.687 & 145.678 & 152.485 & 159.433 \\
\hline
\end{tabular}

Source: Turkey's National Renewable Energy Action Plan, 2014: 65-66

Table 4 shows the expected amount of renewable energy production from renewable energy sources. With the realization of the expected amounts shown in Table, current developed and common fossil fuel combined cycle gas turbine units will be replaced by renewable energy technologies, the amount of the energy import will be reduced at the same amount with the energy obtained from these resources, $127 \mathrm{TWh}$ of the total energy (30\% of total energy demand) will be obtained from renewable energy resources by 2030. It is planned to generate $159.433 \mathrm{GWh}$ of energy as a result of the investments in renewable energy by 2023. It is predicted that once the amounts expected to be obtained from renewable energy resources are reached, it will help to prevent 47 million tons of $\mathrm{CO} 2$ emission and the economic value of it will be 1.2 billion USD (Ministry of Energy and Natural Resources of Turkey).

According to the actual figures, Turkey's total greenhouse gas emission was calculated as 187 MtCO2 in 1990; this figure gradually increased and reached $380 \mathrm{MtCO} 2$ in 2007 and the same amount was calculated as 459,1 MtCO2 in 2013 (Ministry of Environment and Forestry, 2011:6). According to the estimations made, this amount will rise to $590 \mathrm{MtCO} 2$ in 2020 and $852 \mathrm{MtCO} 2$ in 2030 (NERA Economic Consulting, 2011: vii). A difference is observed between the study carried out by NERA, Bloomberg New Energy Finance and IBS Research Consultancy for the European Bank for Reconstruction and Development and Turkey's National Contribution Notice of Intent to Combat Climate Change Scenario about estimations for 2030. On the other hand, it is estimated that if Turkey makes the forecasted renewable energy investments, starts using nuclear technology and increases 
DOI: $10.1515 /$ arhss-2016-0006

Applied Research In Health And Social Sciences: Interface And Interaction, Vol. 13, No. 1, 2016

the energy efficiency, it will be able to achieve the target set in the Letter of Intent given at the Paris Climate Summit for 2030, which is $926 \mathrm{MtCO}_{2}$ greenhouse gas emissions.

\section{Conclusions}

In order to complete development, countries must increase the production of food and services and individuals must increase their goods and services consumption. However, the influence of this increase on nature after a certain point may lead to irrecoverable consequences. The environmental awareness which passed through several phases since the Stockholm conference held in 1972, during which nation states realized this pressure and began to search for a solution, finally reached a consensus on reducing emission amounts with the participation of 195 countries at the Paris Climate Summit in 2015. With the Paris Convention, countries agreed on keeping the temperature rise below 2 degrees Celsius and continuing at 1.5 degrees Celsius. All countries undertook responsibilities according to their development levels.

Turkey is among these countries. For the first time since 1972, Turkey presented the National Contribution Notice of Intent to Combat Climate Change to the summit. According to this, by committing to reduce emission rate by $21 \%$ with decrease from increase method within 2020-2030 period, Turkey plans to increase the emission amount from 449 million tons (the amount in 2015) to 929 million tons in 2030. Turkey plans to reach this target by passing to renewable energy with low carbon content, starting to use nuclear energy and carrying out energy efficiency activities. In line with this target, Turkey is planning to obtain $127 \mathrm{TWh}$ energy (equal to $30 \%$ of total energy demand) from renewable resources, start to operate at least one nuclear energy power plant and carry out activities to raise the energy efficiency. If Turkey implements the policies determined as targets, it may reach emission ratio it desires.

\section{References}

Alada A. B., Gurpınar E. ve Budak S. (1993). Rio Konferansı Üzerine Düşünceler [Thoughts on the Rio Conference]. İstanbul Üniversitesi Siyasal Bilgiler Fakültesi Dergisi, say1 3-4-5.

Aydın, F. F. (2010). Enerji Tüketimi Ve Ekonomik Büyüme [Energy Consumption and Economic Growth]. Erciyes Üniversitesi İktisadi ve İdari Bilimler Fakültesi Dergisi, 318 Sayı: 35, Ocak-Temmuz. pp.317340.

Barbour, E. C. (2010). International Agreements on Climate Change: Selected Legal Questions, Congressional Research Service. CRS Report for Congress. (Accessed on 12/03/2016).

Bodansky D. (2010). The Copenhagen Climate Change Conference: A Post-Mortem. Available at: http://www.fao.org/fileadmin/user_upload/rome2007/docs/Copenhagen_Climate_Change.pdf (Accessed on 12/03/2016).

Boston, J. (2008). Global Climate Change Policies: From Bali to Copenhagen and Beyond. Policy Quarterly, 
4(1), 50-61.

BP Energy Outlook 2030 (2015). http://www.bp.com/content/dam/bp/pdf/energy-economics/energy-outlook2015/bp-energy-outlook-booklet_2013.pdf (Accessed on 12/03/2016).

C2ES 2020 Country Emission Targets (2011). Available at: http://www.c2es.org/international/historyinternational-negotiations/2020-targets (Accessed on 12/03/2016).

European Environment Agency, Annual European Union Greenhouse Gas Inventory 1990-2013 and Inventory Report (2015). Submission to the UNFCCC Secretariat, EEA Technical Report, No19/2015.

Hamilton, J., D. (1983). Oil and the Macroeconomy since World War II. The Journal of Political Economy, 91(2), 228-248.

Hong-Yuan, Y., \& Ve Zhu Song-Li (2015). Toward Paris: China and climate change negotiations. Advances in Climate Change Research, 6(2015), 56-66.

International Energy Agency (IEA). Available at: www.iea.org/2016. (Accessed on 12/03/2016).

IKV, 2020’ye Doğru Kyoto-Tipi İklim Değişikliği Müzakereleri Avrupa Birliği’nin Yeterliliği ve Türkiye’nin Konumu [Kyoto-Type Climate Change Negotiations Towards 2020, Adequacy of the European Union and Turkey's Position] (2013). İktisadi Kalkınma Vakfı Yayınları Yayın No: 268, İstanbul

Karakaya, E., \& Ozcag, M. (2004). Sürdürülebilir Kalkınma ve İklim Değişikliği: Uygulanabilecek İktisadi Araçların Analizi [Sustainable Development and Climate Change: the Analysis of Economic Toolsto be Applied]. Kırgızistan-Türkiye Manas Üniversitesi, I. Maliye Konferansı.

Kates, R.W., Parris, T. M., \& Leiserowitz, A. A. (2005). What is Sustainable Development? Goals, Indicators, Values and Practice, Environment. Science and Policy for Sustainable Development, 47(3), 8-21.

Ren21 Global Status Report (2015). Available at: http://www.ren21.net/wp-content/uploads/2015/07/REN12GSR2015_Onlinebook_low1.pdf (Accessed on 12/03/2016).

Ottinger, R. L. (2010). Introduction: Copenhagen Climate Change Conference--Success Or Failure? Peace Environmental Law Review, 27(2), Article 1.

Soytas, U., \& Sar1, R. (2003). Energy consumption and GDP: causality relationship in G-7 countries and emerging markets. Energy Economics, 25(2003), 33-37

T.C. Çevre ve Orman Bakanlı̆̆l, Ulusal İklim Değişikliği Strateji Belgesi [National Strategy Document on Climate Change] (2009). p.5.

T.C. Dış İşleri Bakanlı̆̆l, Türkiye’nin Enerji Profili Ve Stratejisi [Turkey's Energy Profile and Strategy] (2016). Available at: http://www.mfa.gov.tr/default.tr.mfa. (Accessed on 12/03/2016).

T.C. Enerji ve Tabi Kaynaklar Bakanlı̆̆l (ETKB), Türkiye Ulusal Yenilenebilir Enerji Eylem Planı [Turkey's National Renewable Energy Action Plan] (2014). pp. 65-66.

T.C. Enerji ve Tabi Kaynaklar Bakanlı̆̆ı (ETKB), İklim Değişikliği Müzakereleri ve Türkiye [Climate Change Negotiations and Turkey] (2016). Available at: http://www.enerji.gov.tr/tr-TR/Sayfalar/UluslararasiMuzakereler (Accessed on 12/03/2016).

T.C. Kalkınma Bakanlı̆̆ı, 10. Kalkınma Planı, Yerli Kaynaklara Dayalı Enerji Üretim Programı Eylem Planı [10th Development Plan, Action Plan for Energy Production Based on Domestic Resources Program], 
Kasim (2014). (Accessed on 12/03/2016).

The Climate Group, A Climate Group Assessment, The Copenhagen Climate Summit (2010). Available at: http://www.theclimategroup.org/ assets/files/TCG-Copenhagen-Assessment-ReportJan10.pdf (Accessed on 12/03/2016).

Thorvaldsdottir, S., \& Valdre, P. (2009). Negotiating Climate Change From Bali to Copenhagen. International NY: Peace Institute.

Türkiye Cumhuriyeti Niyet Edilen Ulusal Olarak Belirlenmiş Katkl [Nationally Determined Intended Contribution] (2015). Available at:https://www.csb.gov.tr/...The_INDC_of_TURKEY_v_15_19_30TR.pdf (Accessed on 12/03/2016).

Türkiye Istatistik Kurumu (TÜIKK), Seragazı Emisyon Envanteri [Greenhouse Gas Inventory] (2013). (Accessed on 12/03/2016).

Türkyılmaz, O. (2015). Enerji Politikaları Artan Bağımlılık Çıkmazında, Ocak 2015 İtibarıyla Türkiye’nin Enerji Görünümü Raporu [Energy Policies are in Increasing Dependence Dilemma, Turkey's Energy Outlook Report As of January 2015]. Enerji Piyasaları ve Politikaları Enstitüsü, Bülten, Şubat, Sayı:200

UN, Kyoto Protocol To The United Nations Framework Convention On Climate Change (1998). Available at: https://unfccc.int/resource/docs/convkp/kpeng.pdf (Accessed on 12/03/2016).

UN, Report of the World Summit on Sustainable Development, Johannesburg, South Africa (2002). Available at: http://www.unmillenniumproject.org/documents/131302_wssd_report_reissued.pdf (Accessed on 12/03/2016).

UN, The Future We want Report of the United Nations Conference on Sustainable Development (2012). Brazil. Available at: https://sustainabledevelopment.un.org/rio20.html (Accessed on 12/03/2016).

UNFCCC, Report of the Conference of the Parties serving as the meeting of the Parties to the Kyoto Protocol on its eighth session (2012). Available at: http://unfccc.int/resource/docs/2012/cmp8/eng/13a02.pdf (Accessed on 12/03/2016).

UN, Adoption of the Paris Agreement (2015). FCCC/CP/2015/L.9/Rev.1. Available at: https://unfccc.int/resource/docs/.../109r01.pdf (Accessed on 12/03/2016).

UNFCCC, United Nations Framework Convention on Climate Change Fact sheet: The Kyoto Protocol (1997). Available

https://unfccc.int/files/press/backgrounders/application/pdf/fact_sheet the kyoto_protocol.pdf

(Accessed on 12/03/2016).

United Nations (UN), Adoption of the Paris Agreement (2015). FCCC/CP/2015/L.9/Rev.1. Available at: https://unfccc.int/resource/docs/2015/cop21/eng/109r01.pdf (Accessed on 12/03/2016).

United Nations, Report Of The United Nations Conference on the Human Environment (1972). Stockholm.

Xue-Du L. (2014). Assessment of achievements of the Lima Climate Change Conference and perspectives on the future. Advances in Climate Change Research, 5, 219-223

Yanar, R. ve Kerimoğlu, G. (2011). Türkiye'de Enerji Tüketimi, Ekonomik Büyüme Ve Cari Açık İlişkisi [The Relations Between Energy Consumption, Economic Growth and Current Account Deficit in Turkey]. Ekonomi Bilimleri Dergisi, 3(2), 191-201. 
DE DE GRUYTER

OPEN

DOI: 10.1515/arhss-2016-0006

Applied Research In Health And Social Sciences: Interface And Interaction, Vol. 13, No. 1, 2016

Zillman, J. W. (2009). A history of climate activities. World Meteorological Organization (WMO) Bulletin,

58(3). Available at: https://public.wmo.int/en/bulletin/history-climate-activities (Accessed on 12/03/2016). 